\title{
Measuring the Tourist Satisfaction Towards the Man-made Theme Park in Bangladesh: A Comprehensive Study on Some Selective Sites
}

\author{
S. M. Shahedul Alam ${ }^{1, ~ *, ~ M d . ~ F e r d u s h ~ R a h m a n ~}{ }^{2}$, Shaikh Majedul Huq ${ }^{2}$, Md. Kamruzzaman ${ }^{1}$ \\ ${ }^{1}$ Department of Tourism and Hospitality Management, Pabna University of Science and Technology, Pabna, Bangladesh \\ ${ }^{2}$ Department of Marketing, Begum Rokeya University, Rangpur, Bangladesh
}

Email address:

shahedul1992@gmail.com (S. M. S. Alam), ferdushhstu@yahoo.com (Md. F. Rahman), huqsajib@yahoo.com (S. M. Huq),

kamrul_mba@yahoo.com (Md. Kamruzzaman)

*Corresponding author

\section{To cite this article:}

S. M. Shahedul Alam, Md. Ferdush Rahman, Shaikh Majedul Huq, Md. Kamruzzaman. Measuring the Tourist Satisfaction Towards the Manmade Theme Park in Bangladesh: A Comprehensive Study on Some Selective Sites. International Journal of Hospitality \& Tourism Management. Vol. 4, No. 1, 2020, pp. 8-14. doi: 10.11648/j.ijhtm.20200401.12

Received: February 8, 2019; Accepted: March 5, 2020; Published: April 28, 2020

\begin{abstract}
Now a day's tourism becomes an emerging sector in all over the world. The main objective of the study is to identify the factors that affect individual choosing to a theme park and to measure the tourist satisfaction towards the theme park. Descriptive nature of the study is conducted based on primary and secondary data. The primary data of the study is collected through a focus group study and questionnaire survey. The respondents of the study are selected by random sampling method, considerably who have visited the theme park tourist destination in Bangladesh, from January to March 2017. Secondary data analysis and focus group discussion of this study finds out 36 quality characteristics that can affect tourist satisfaction towards the tourist destination. Factor analysis the study classified all the thirty-six quality characteristics under six major variables. These are entitled through attraction and amusement facility, hotel and restaurant services, cost of the visit, safety and security, hygienic environment, administration and support service. The study developed a conceptual framework based on the factor analysis. There are six hypotheses are drowned to test the conceptual framework. The results of the regression analysis of the study test all the six hypotheses and got the positive result that the model is fitted. It also found that tourists are satisfied with attraction and amusement facility, hotel and restaurant services and administration and support service but they are not satisfied with the cost of the visit, safety and security, hygienic environment factors. The study recommended that the theme park destination authority should take action to improve safety, security and hygienic environment-related issues. The authority should consider their pricing issues or show the logical reason for high price charging. Finally, it can be stated that the tourism sector will become sustainable if the destination authority considers the 36 quality characteristics and other recommendations of the study when they plan for theme park development.
\end{abstract}

Keywords: Theme Park, Tourist Satisfaction, Bangladesh Tourism

\section{Introduction}

Tourism sector is expanding its hand in different event and activities day by day. At the same time the travelling process is becoming faster, easier and the tourism arena is becoming wider. Now the demand for better service is increasing day by day, different tourist destinations offer various innovative ideas \& services to attract the tourist. In order to survive in this competitive field of the tourism sector, all tourism organizations are looking for better services opportunities to provide their targeted tourist.

According to World Travel \& the Tourism Council, while economic growth going forward to face many challenges - as both governments and the private sector in many developed economies seek to reduce their debts, and as the prices of oil and other commodities rise - the Travel \& Tourism industry is still expected to be one of the world's fastest growing sectors. Tourism is one of the largest and fastest growing 
sectors of the global economy, tourism consists of many small and medium sizes of enterprises which try to be successful in an extremely competitive and rapidly changing business environment. To create competitive advantage in this environment, a small tourism enterprise has to choose a powerful strategy.[1]

The tourism sector can play an important role as a driving force of economic development by contributing in the GDP of Bangladesh. Tourism expenditures and the export related goods and services generate income to the economy of Bangladesh and can simulate the investment necessary to finance growth in other economic sectors. Government may earn revenue by imposing taxes on the popular products demanded by the tourists.[2] Tourism offers the job opportunity for different classes of people and thereby contributes to alleviate poverty from Bangladesh. Tourism generates jobs directly through hotels, restaurants, taxis, souvenir sales; and indirectly, through the supply of goods and services needed by tourism-related business. In addition, tourism can include the local government to make infrastructural improvements and also make an important contribution to a country's overall development. [3]

The Theme Park Tourist Destination authority need to improve their tourist sites' quality, profitability and sustainability. Each and every factor's involving with the quality, profitability and sustainability of a tourist destination reflect through the tourist satisfaction towards it. For this reason, marketers need to measure tourist satisfaction towards their tourist destination.

Because of having a hidden opportunity to take place in the world's tourism industry, this paper has taken a diminutive attempt to discern some of the factors such as the real scenario of tourist destination, factors that involving with tourist satisfaction, problems in tourism sectors in Bangladesh. This paper has also taken an attempt to suggest the ways that can improve this sector in Bangladesh.

\section{Objectives of the Study}

The main objective of the study is to measure the tourist satisfaction towards the Theme Park in Bangladesh. Based on the title of the study some others related objectives are given billow-

a) To identify the factors that affect for individual choosing to a Theme Park.

b) To measure the tourist satisfaction towards the Theme Park.

\section{Review of Literature}

\subsection{Theme Park}

In general, theme parks can be defined as a subset of visitor attractions. Visitor attractions are described as permanent resources which are designed, controlled and managed for the enjoyment, amusement, entertainment, and education of the visiting public There are the main types of managed attractions for visitors: ancient monuments; historic buildings; parks and gardens; theme parks; wildlife attractions; museums; art galleries; industrial archeology sites; themed retail sites; amusement and leisure parks.[4] Single units, individual sites or clearly defined small-scale geographical areas, which are accessible and motivate large numbers of people to travel some distance from their home, usually in their leisure time, to visit them for a short, limited period of time.

\subsection{Tourist Satisfaction}

Satisfaction is defined as a person's feelings of pleasure or disappointment resulting from comparing a product are perceived performance (or outcome) in relation to his or her expectations. [5] A satisfaction is a learned predisposition behaves in a consistently favorable or unfavorable manner with respect to a given objective. [6] Satisfaction is the tourist's emotional state after experiencing the trip. [7] Therefore, evaluating satisfaction in terms of a travelling experience is a post-consumption process. [8] Satisfaction can be used as a measure to evaluate the products and services offered at the destination.[9] Customer satisfaction can be estimated with a single item, which measures the overall satisfaction. [10] Besides the global perception about the outcome alone, the degree of satisfaction can be evaluated through specific service attributes.[11] Satisfied customers can bring lot of other advantages for the service providers as a ripple effect including loyalty to service provider, engagement in positive word-of-mouth promotion and paying premium prices.[12] Satisfaction as customer's emotional reaction to a specific product/service experience.[13] Tourist satisfaction is considered one of the prime variables to sustain competitive business in the tourism industry because it affects the choice of destination, consumption of products and services.[14] The consumer's response to the evaluation of the perceived discrepancy between prior expectations (or some norm of performance) and the actual performance of the product as perceived after its consumption.[15] Nine attributes of customer satisfaction, namely employee attitudes, location, room, price, facilities, reception, services, parking and food and beverage.[16]

\subsection{Factors Affecting Towards the Tourist Satisfaction}

A wide range of elements may influence the vacationer fulfillment: accommodation and visitor results of goal, nature of administrations, wellbeing, past experience and desires, traveler exercises, goal picture and others. [17] A model on return intentions to Spanish destinations through destination image, perceived quality and satisfaction as explanatory variables. [18] Tourism is a complex functional system which is a blending of five major components; Tourists, Attractions, Service facilities, Transportation and Proper direction of information. [19] A model based on revisiting intentions that establishes satisfaction as both a predictor of revisiting intentions and as a moderator variable between this construct and perceived attractiveness, perceived quality of 
service and perceived value for money.[20] The satisfaction attributes included attractions, lodging, dining, shopping, accessibility, activities and events and environment. Different attributes like perceived attractions, perceived quality, perceived risk and perceived value used measure the satisfaction of tourists. Comfort facilities, safety and infrastructure, cultural attractions \& shopping, tourist attractions and ambience and variety and accessibility affects tourist satisfaction. The main factors of tourists' loyalty income satisfaction with natural environments, social environments, facilities, operations, and management, as well as current residential locations and revisiting. It was believed that a range of ways to develop more sustainable forms of tourism emerged from the work, including lengthening stays, guide/driver capacity building, and partnership working with tour operators to improve marketing, increase satisfaction rates, and diversify the product. [21] It was find out that nine factors such as service quality, natural beauty, know destination, convenient lodging, adventure, security, effective and efficient transportation, safe and quality food and shopping facility which are associated with the selection of a destination but overlooks the rotational items e.g., entertaining options, different rides etc. and also available authentic informational source regarding the destination.[22] Independently identify seven factors associated with Huangshan Scenic Area as perceived service, perceived price, perceived sentimental value, perceived social value, overall perceived, satisfaction, and trust as the key factors influencing the customer retention. [23] Four crucial factors influencing customer retention in the hotel and resort industry including customer satisfaction, service quality, switching costs and trust. There is a positive relationship between service quality and customer retention. It was reviled that environmental factors are more important while the price factor is less important issue for tourist.[24] Tourist Perception constructs has been influenced by factors like Historical and Cultural Attractions, Destination Affordability, Travel Environment, Natural Attractions, Entertainments and Infrastructure. Satisfaction construct has been influenced by factors like Entertainments, Destination Attractions and Atmosphere, Accommodation, Food, Transportation Services and Shopping. The destination loyalty construct has influenced by intentions to revisit, word of mouth promotion and recommending to others.[25] The most significant factor affecting the overall satisfaction is the cost of Staying, and other significant factors are hospitality, attractions and accessibility, and infrastructure. [26] The satisfied visitors also will influence the repetition of visitor to the theme park and build loyal customer and influence repeat visitor. it was revealed that better perceptions of hotel ambience and staff courtesy, food and beverage products, staff performance and knowledge, reservation services and financial value were more likely to develop customer satisfaction which was, in turn, more likely to result in positive behavioral intentions such as revisit intentions or intentions to recommend it to others. [27] It was identified that tourist destinations' attractions refer to the attractions as being permanent resources managed for visitor enjoyment, entertainment and education. [28] Destinations that fail to maintain the necessary infrastructure or build inappropriate infrastructure face significant risks. A destination's attractiveness can be diminished by violence, political instability, natural catastrophe, and adverse environmental factors and overcrowding. [29]

From the literature review it has been observed that the destination attractions become the hottest issue in tourism business profitability as well as the capabilities of earning foreign currency. The study can provide a clear understanding about a theme Park tourist destination attraction and help to find out the factors that affect for individual choosing of a tourist destination. Furthermore, tourist destination authority become able to develop multiple problem-solving strategies and they can also improve their decision-making skills through the assimilation of this study.

\section{Methodology of the Study}

The study, descriptive in nature, has been conducted based on primary and secondary data. The tourists visited the theme park tourist destinations' during January to March, 2017 at some selective sites in Bangladesh is considered as the total population for this study. The respondents of the study have been selected through random sampling method, considerably who have visited the Theme Park namely Shopnopuri Artificial Amusement Park, Vinna Jagot, Nandan Park, Fantasy Kindom, Dreamland Amusement Park, Shishu Park and like some others theme parks.

The primary data of the study have been collected through focus group discussion and questionnaire survey method. Focus group discussion is used for general concept development about the study and questionnaire survey is used for data collection about the tourist satisfaction towards the tourist destination. This study tries to focus on 36 "Quality Characteristics" which have been gotten from the reviews of literature and focus group discussion. The respondents have been responded each "Quality Characteristic" under the seven-point Semantic Scale. Where "Strongly Agree" was dictated as the highest level of preference and "Strongly Disagree" was dictated as the highest level of dissatisfaction. Behind those "Quality Characteristic" questions some of the demographic questions were also asked for more interpretation of respondents' feedback. The developed questionnaire has been pre-tested with a few tourists to ensure the quality of the questions.

The questionnaire was distributed directly to respond as a study sample. In this study, researcher distributed 800 questionnaires to respondent for measuring the tourist satisfaction towards the tourist destination. Among them, 760 respondents returned the filled-up questionnaires. Due to respondent's inability, unconsciousness and excessive missing values 30 questionnaires were dropped. So, finally the sample size stands at 730 (Seven Hundred Thirty).

The secondary data and information will be collected from a range of sources. The secondary data has been taken from 
the websites of the different Ministries of Bangladesh Government and different publications. The collected data are analyzed by various statistical tools and techniques including frequency distribution, and multiple regression analysis through the data processing software SPSS 20.0 version.

\section{Results of the Study}

Results of the study include the sections i.e. focus group discussion of the study, demographic status of the respondents, descriptive statistics of the study, factor analysis of the study, conceptual framework development, hypothesis development, regression analysis of the study and test of hypothesis.

\subsection{Focus Group Discussion of the Study}

Focus group discussion of this study finds out some of the factors that can affect tourist satisfaction towards the tourist destination. The tourist satisfaction become positive when it has some quality characteristics i.e. it is full of different tourist attraction, it has sporting event facility, it provides pleasure to the tourist, it has the opportunity to enjoy cultural events, it has different kinds of rides, mind refreshing events, it makes the tourist adventurous, it provides amusement to the tourist, it creates an appeal on tourist mind, its becomes good looking, it has well decoration, it has available healthy and hygienic food, it has a large variety of food items, it has staff facilities, it has restaurants with homely environment, it provides reasonable entering cost, it provides reasonable food cost, it provides it provides reasonable cost of shopping items, it provides reasonable cost of playing various rides, it provides reasonable transportation cost, it is safe for tourist, it is observed by CC camera, it has available safe guard, it has available tourist guide, it has a monsoon weather, it has cold environment, it is neat and clean, it does not involve with any environmental pollution activities, it has available supply of pure drinking water, it has available sanitation facility, it ensures well communication facility, it has well transportation facility, it has available helpline facility, it has responsible administration, it has available information center, it has free internet access facility and available parking facility.

\subsection{Demographic Status of the Respondents}

Table 1 shows that 43.7 percent of the tourist age is 18 to 35 years; the major occupations of the tourists are services (28.2 percent) and students (41.0 percent); the number of male tourists is 56.8 percent; fifty percent of the tourist income is below twenty thousand taka. Table 1 shows demographic status of the respondents.

Table 1. Demographic status of the respondents

\begin{tabular}{lll}
\hline Items & Frequency & Percent \\
\hline Tourist Age & & \\
Below 18 years & 162 & 22.7 \\
18 to 35 years & 319 & 43.7 \\
\hline
\end{tabular}

\begin{tabular}{|c|c|c|}
\hline Items & Frequency & Percent \\
\hline 35 to 50 years & 171 & 23.4 \\
\hline 50 years or more & 78 & 10.7 \\
\hline \multicolumn{3}{|l|}{ Tourist Major Occupation } \\
\hline Services & 206 & 28.2 \\
\hline Business & 93 & 12.7 \\
\hline Student & 299 & 41.0 \\
\hline Farmer & 51 & 7.0 \\
\hline Others & 81 & 11.1 \\
\hline \multicolumn{3}{|l|}{ Tourist Education Level } \\
\hline Uneducated & 74 & 10.1 \\
\hline Below SSC & 109 & 14.9 \\
\hline $\mathrm{SSC}$ & 239 & 32.7 \\
\hline HSC & 154 & 21.1 \\
\hline Graduate & 154 & 21.1 \\
\hline \multicolumn{3}{|l|}{ Tourist Marital Status } \\
\hline Male & 415 & 56.8 \\
\hline Female & 315 & 43.2 \\
\hline \multicolumn{3}{|l|}{ Tourist Home Division } \\
\hline Rangpur Division & 295 & 40.4 \\
\hline Rajshahi Division & 163 & 22.3 \\
\hline Dhaka Division & 76 & 10.4 \\
\hline Sylet Division & 83 & 11.4 \\
\hline Khulna Division & 22 & 3.0 \\
\hline Barishal Division & 53 & 7.3 \\
\hline Chitagong Division & 38 & 5.5 \\
\hline \multicolumn{3}{|l|}{ Tourist Monthly Income } \\
\hline Light Income Tourist (Below Tk. 10000) & 186 & 25.5 \\
\hline Low Income Tourist (Tk. 10000-20000) & 177 & 24.2 \\
\hline Middle Income Tourist (Tk. 20000-30000) & 157 & 21.5 \\
\hline High Income Tourist (Tk. 3000-40000) & 93 & 12.7 \\
\hline $\begin{array}{l}\text { Heavy Income Tourist (Tk. } 40000 \text { or More) } \\
\text { Per Day Expense for individual }\end{array}$ & 117 & 16.0 \\
\hline Light User (Below Tk. 1000) & 396 & 54.2 \\
\hline Low User (Tk. 1000-2000) & 81 & 11.1 \\
\hline Medium User (Tk. 2000-3000) & 76 & 10.4 \\
\hline High User (Tk. 4000 or More) & 114 & 15.6 \\
\hline Heavy User (Tk. 4000 or More) & 63 & 8.63 \\
\hline
\end{tabular}

\subsection{Descriptive Statistics of the Study}

Table 2 shows that the mean value of tourists' satisfaction determining factor mind refreshing (5.3356) adventurous things (5.1548) service-oriented staff (5.2356), tourist safety (5.2712), science and technological adventure (5.3452) are very high than the other factors. The mean of the total customer satisfaction of seven hundred and thirty tourists is 4.4898 with a std. deviation of 1.20344 in the seven-point Likert scale.

Table 2. Descriptive Statistics of the Study.

\begin{tabular}{llll}
\hline $\begin{array}{l}\text { Factors determining tourist's } \\
\text { satisfaction }\end{array}$ & N & Mean & $\begin{array}{l}\text { Std. } \\
\text { Deviation }\end{array}$ \\
\hline Variety of Food Items & 730 & 4.2671 & 1.20408 \\
Entering Cost & 730 & 4.5137 & 1.16438 \\
Available Safeguard & 730 & 4.6849 & 1.04464 \\
Rides for Kids & 730 & 4.9534 & 1.42504 \\
Mind Refreshing & 730 & 5.3356 & 1.19370 \\
Adventurous Things & 730 & 5.1548 & 1.32999 \\
CC Camera Observation & 730 & 3.2548 & 1.39989 \\
\hline
\end{tabular}




\begin{tabular}{llll}
\hline Factors determining tourist's & N & Mean & $\begin{array}{l}\text { Std. } \\
\text { Deviation }\end{array}$ \\
satisfaction & 730 & 3.0329 & 1.19166 \\
\hline Neat \& Clean & 730 & 5.2356 & .88384 \\
Service Oriented Staff & 730 & 4.7438 & 1.17420 \\
Well Decoration & 730 & 3.2288 & 1.13963 \\
Cost of Playing Rides & 730 & 4.1014 & 1.43659 \\
Cost of shopping items & 730 & 4.4616 & 1.20095 \\
Appeal Creating & 730 & 4.6068 & 1.02384 \\
Homely Hotel \& Restaurant & 730 & 3.2603 & 1.34794 \\
Environment & 730 & 3.7534 & 1.30821 \\
No Environment Pollution & 730 & 4.3836 & 1.36817 \\
Food Cost & 730 & 4.6507 & 1.32814 \\
Sanitation Facility & 730 & 4.4932 & 1.04394 \\
Sporting Event Facility & 730 & 5.2712 & .90593 \\
Man-made Architecture & 730 & 3.5055 & 1.51828 \\
Tourist Safety & 730 & 4.0918 & 1.46231 \\
Man-Made Attractions & 730 & 4.4616 & .97810 \\
Over Crowded Area & 730 & 4.4781 & 1.28841 \\
Enjoyment of Cultural Event & 730 & 4.8082 & 1.02583 \\
Monsoon Weather & 730 & 3.4932 & .97603 \\
Rides for Kids & 730 & 5.1822 & 1.36423 \\
WiFi Facility & 730 & 5.2027 & 1.27549 \\
Healthy \& Hygienic Food & 730 & 5.3452 & 1.31625 \\
Homely Environment & 730 & 5.1288 & 1.13668 \\
Science and Technological Adventure & 730 & 4.8178 & 1.17517 \\
Swimming Pull and water Rides & 730 & 5.4562 & .97647 \\
Facilities & 430 & 4.0233 & 1.25413 \\
Pure Drinking Water & 4.8740 & 1.03731 \\
Help Line Facility & 4.5699 & 1.16000 \\
Available Beautiful Garden & & & \\
Information Availability & 7.8068 & 1.26457 \\
Internet Facility & 730 & 1.20344 \\
Parking Facility & 730 & & \\
Total & 730 & & \\
\hline
\end{tabular}

\subsection{Factor Analysis of the Study}

Factor analysis the study classified all the factors under six major variables. These are entitled through attraction and amusement facility, hotel and restaurant services, cost of the visit, safety and security, hygienic environment, administration and support service with the help of the reviews of literature and focus group discussion understanding. Those major six variables are defined as:

Attraction and amusement facility includes it has some quality characteristics, i.e. it is full of different tourist attractions, it has sporting event facility, it provides pleasure to the tourist, it has the opportunity to enjoy cultural events, it has different kinds of rides, it refreshes your mind, it makes adventurous for you, it provides amusement to you, it creates an appeal on your mind, it becomes better looking.

Hotel and restaurant services include, it has well decorated, it has available healthy and hygienic food, it has a large variety of food items, it has staff facilities, it has homely environment

Costs of visit includes it provides reasonable entering cost, it provides reasonable food cost, it provides it provides reasonable cost of shopping items, it provides reasonable cost of playing various rides, it provides reasonable transportation cost.

Safety and security include it is safe for tourist, it is observed by CC camera, it has an available safeguard, it has an available tourist guide.
Hygienic environment includes it has a monsoon weather, it has cold environment, it is neat and clean, it has an available supply of pure drinking water, it has an available sanitation facility.

Administration and support service include, it has well transportation facility, it has responsible administration, it has an available information center, and available parking facility.

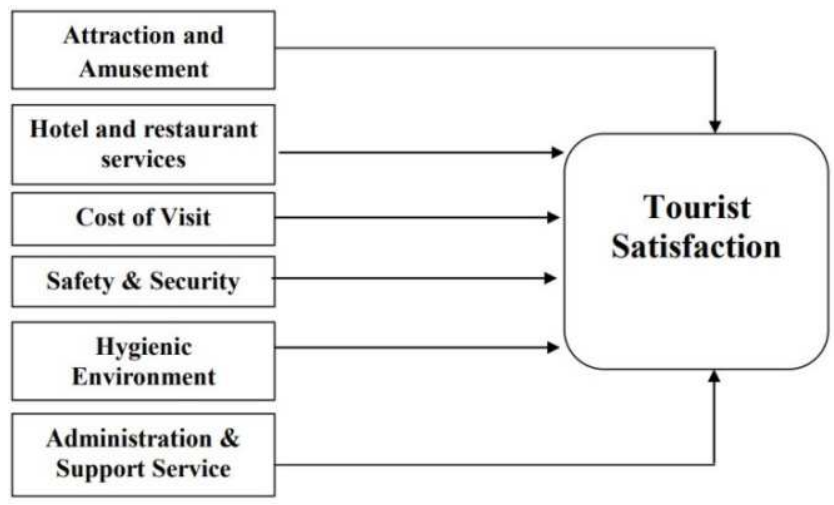

Figure 1. Tourist Satisfaction Measurement Model.

\subsection{Conceptual Framework Development}

Author used this model to measure the tourists' satisfaction towards the tourist destination.

So, the fitted Regression model is...

$$
Y=\beta_{0}+\beta_{1} X_{1}+\beta_{2} X_{2}+\beta_{3} X_{3}+\beta_{4} X_{4}+\beta_{5} X_{5}+\beta_{6} X_{6}+e
$$

Here, $Y=$ Overall Tourist satisfaction towards the Manmade Theme Park

$\mathrm{X}_{1}$ - Attraction and amusement facility

$\mathrm{X}_{2}$ - Hotel and restaurant services

$\mathrm{X}_{3}$ - Cost of visit

$\mathrm{X}_{4}$-Safety and security

$\mathrm{X}_{5}$ - Hygienic environment

$\mathrm{X}_{6}$-Administration \& support service

\subsection{Hypothesis of the study}

Conceptual Framework of the study motivates to test some hypothesis. These alternative hypotheses are:

H1: Tourists are satisfied with the attraction and amusement facility the theme park tourist destination in Bangladesh.

$\mathrm{H} 2$ : Tourists are satisfied with the Hotel and restaurant service of the theme park tourist destination in Bangladesh.

H3: Tourists are satisfied with the Cost of visit of the theme park tourist destination in Bangladesh.

H4: Tourists are satisfied with the Safety and security of the theme park tourist destination in Bangladesh.

H5: Tourists are satisfied with the Hygienic environment of the theme park tourist destination in Bangladesh.

H6: Tourists are satisfied with the Administration \& support service of the theme park tourist destination in Bangladesh. 


\subsection{Regression Analysis of the Study}

$\mathrm{R}^{2}$, the coefficient of determination, implies that "over all tourist satisfaction" has explained $68.5 \%$ by the independent variables, i.e. administration \& support service, cost of visit, attraction and amusement facility, hygienic environment, hotel and restaurant services, safety and security.

The ANOVA test shows that the F - value 16.626 and $\mathrm{P}$ value $(0.00)$ is less than 0.05 , then study hypothesis is significant at the $5 \%$ level. This also implies that the model is significant. That means administration \& support service, cost of the visit, attraction and amusement facility, hygienic environment, hotel and restaurant services, safety and security can significantly explain "over all tourist satisfaction" towards the theme park tourist destination in Bangladesh.

From the coefficients' analysis, it is seen that tourist are satisfied with attraction and amusement facility, hotel and restaurant services, administration \& support service of the theme park tourist destination in Bangladesh. Because the sig. values of attraction and amusement facility (.000), hotel and restaurant services (.000), administration \& support service (0.016). As per the table it also be explained that tourists are not satisfied cost of visit, hygienic environment, safety and security of the tourist destination. Because the sig. values of cost of visit (.057), hygienic environment (.503), safety and security (.137).

The regression line of the study $\mathrm{Y}=\beta 0+\beta 1 \mathrm{X} 1+\beta 2 \mathrm{X} 2+$ $\beta 3 \mathrm{X} 3+\beta 4 \mathrm{X} 4+\beta 5 \mathrm{X} 5+\beta 6 \mathrm{X} 6$ +e may be drown as like, Tourists $\quad$ satisfaction $=5.551+\quad(.421) \mathrm{X} 1+\quad(.656) \mathrm{X} 2+$ $(.212) \mathrm{X} 3+(.071) \mathrm{X} 4+(.130) \mathrm{X} 5+(.250) \mathrm{X} 6+.777$.

\subsection{Tests of Hypothesis}

$\mathrm{H}_{1}$ : Alternative hypothesis 1 is accepted at the $95 \%$ confidence level, since the sign value attraction and amusement facility is 0.000 on the coefficients' table. So, it can be concluded that the tourists are satisfied with the attraction and amusement facility of the theme park tourist destination in Bangladesh.

$\mathrm{H}_{2}$ : Alternative hypothesis 2 is accepted at the $95 \%$ confidence level, since the sign value hotel and restaurant services are 0.000 on the coefficients' table. So, it can be concluded that the tourists are satisfied with the hotel and restaurant services of the theme park tourist destination in Bangladesh.

$\mathrm{H}_{3}$ : Alternative hypothesis 3 is rejected at the $5 \%$ level of significance, since the sign value satisfied costs of the visit is 0.057 on the coefficients' table. So, it can be concluded that the tourists are not satisfied with the costs of the visit of the theme park tourist destination in Bangladesh.

$\mathrm{H}_{4}$ : Alternative hypothesis 4 is rejected at the $5 \%$ level of significance, since the sign value safety and security is 0.503 on the coefficients' table. So, it can be concluded that the tourists are not satisfied with the safety and security related services of the theme park tourist destination in Bangladesh.

$\mathrm{H}_{5}$ : Alternative hypothesis 5 is rejected at the $5 \%$ level of significance, since the sign value hygienic environment is 0.137 on the coefficients' table. So, it can be concluded that the tourists are satisfied with the hygienic environment of the theme park tourist destination in Bangladesh.

$\mathrm{H}_{6}$ : Alternative hypothesis 6 is accepted at the $95 \%$ confidence level, since the sign value administration \& support service are 0.016 on the coefficients' table. So, it can be concluded that the tourists are satisfied with the administration \& support service of the theme park tourist destination in Bangladesh.

\section{Conclusions and Recommendations}

Based on the secondary data analysis and focus group discussion of this study finds out 36 quality characteristics that can affect tourist satisfaction towards the tourist destination. Factor analysis the study classified all the thirtysix quality characteristics under six major variables. These are entitled through attraction and amusement facility, hotel and restaurant services, cost of the visit, safety and security, hygienic environment, administration and support service. The results of the regression analysis of the study test all the six hypotheses and got the positive result that the model is fitted. It also found that tourists are satisfied with attraction and amusement facility, hotel and restaurant services and administration and support service but they are not satisfied with cost of the visit, safety and security, hygienic environment factors. The study recommended that the theme park destination authority should take action to improve Safety and security issues by observing through CC camera, recruiting safeguard, making availability of skilled tourist guide. They can also take initiative to improve hygienic environment facilitating through monsoon weather, cold environment, neat and clean environment, pure drinking water and sanitation facility. The authority should consider their pricing issues or show the logical reason for high price charging. They also can choose segmented or value-added pricing policy for their product. They also need to maintain the quality and innovativeness of theme park attraction and amusement facility, hotel and restaurant services and administration and support service-related issues. Finally, it can be stated that if the destination authority considers the recommendations then it will become a sustainable profitable sector in all over the world.

\section{References}

[1] Afroz, Nushrat Nahida \& Hasanuzzaman, Md.(2012), 'Problems and Prospects of Tourism in Bangladesh Bandarban District Case' Global Journals Inc. (USA) Volume 12 Issue 23 Version 1.0 p. 11-13.

[2] Tourism board. Available: http://www.tourismboard.gov.bd/2012-03-10-05-0935/mainamati/14 tourism-board/17-touristdestination.html Accessed July 152017.

[3] Malaysia Tourism Promotion Board, (2004), Profile of Tourists by Selected Market 2004, Planning and Research Division, Tourism Malaysia, Kuala Lumpur. 
[4] Rahman, Md. Lutfur, Hossain, S. M. Nawshad\&Miti, SaniaSifat (2010), 'An Overview of Present Status and Future Prospects of the Tourism Sector in Bangladesh', Journal of Bangladesh Institute of Planners, Bangladesh Institute of Planners Vol. 3, r, pp. 65-75, December.

[5] Kotler, P. (2000). Administração de marketing.

[6] Schiffman, L., \& Kanuk, L. L. (2008). Consumer behaviour 7th edition (Perilaku Konsumen). Jakarta: PT. Indeks.

[7] Baker, D. A., \& Crompton, J. L. (2000). Quality, satisfaction and behavioral intentions. Annals of tourism research, 27 (3), 785-804.

[8] Fornell, C. (1992). A national customer satisfaction barometer: The Swedish experience. Journal of marketing, 56 (1), 6-21.

[9] Yu, X. (2012). Co-producing the nature-based adventure tourism experience: tourist, environment and management contributions (Doctoral dissertation, University of Illinois at Urbana-Champaign).

[10] Spreng, R. A., \& Mackoy, R. D. (1996). An empirical examination of a model of perceived service quality and satisfaction. Journal of retailing, 72 (2), 201-214.

[11] Mai, L. W., \& Ness, M. R. (2006). A structural equation model of customer satisfaction and future purchase of mailorder speciality food. International Journal of Business Science and Applied Management, 1 (1), 1-13.

[12] PART, A. Factors influencing customer satisfaction in Malaysia hotel.

[13] Oliver, R. L. (1981). Measurement and evaluation of satisfaction processes in retail settings. Journal of retailing.

[14] Kozak, M., \& Rimmington, M. (2000). Tourist satisfaction with Mallorca, Spain, as an off-season holiday destination. Journal of travel research, 38 (3), 260-269.

[15] Tse, D. K., \& Wilton, P. C. (1988). Models of consumer satisfaction formation: An extension. Journal of marketing research, 25 (2), 204-212.

[16] Barsky, J. D., \& Labagh, R. (1992). A strategy for customer satisfaction. Cornell Hotel and Restaurant Administration Quarterly, 33 (5), 32-40.

[17] Nabi, Nazia \& Zaman, Shituma, (2014), 'The Sources and
Availability of Information for Tourists: A Study on Tourism Sector of Bangladesh' World Journal of Social Sciences. Vol. 4. No. 1. Issue. Pp. 154 - 166 March.

[18] Bigne, J. E., Sanchez, M. I., \& Sanchez, J. (2001). Tourism image, evaluation variables and after purchase behaviour: inter-relationship. Tourism management, 22 (6), 607-616.

[19] Siddiqi, R. (2006), 'Tourism in Bangladesh suffers: Policy makers lack understanding, government lacks strong intention', The Independent March 16th, Dhaka, Bangladesh.

[20] Um, T. M. (2006). U.S. Patent Application No. 29/219, 366.

[21] Okello, M. M., \& Yerian, S. (2009). Tourist satisfaction in relation to attractions and implications for conservation in the protected areas of the Northern Circuit, Tanzania. Journal of Sustainable Tourism, 17 (5), 605-625.

[22] Ahmed, SS. (1986), 'Tourism in Bangladesh', Bangladesh Quarterly, Vol. 6, No. p_6.

[23] Lu, Q., Gao, W., \& Huang, R. (2011). Atomistic simulation and continuum modeling of graphene nanoribbons under uniaxial tension. Modelling and Simulation in Materials Science and Engineering, 19 (5), 054006.

[24] Hossain, M. A. and Nazmin, S., (2006), Development of Tourism Industry in Bangladesh- an empirical study on its problems and prospects, Centre for Tourismand Hotel management Research, University ofDhaka, Dhaka.

[25] Rajesh, R. (2013). Impact of tourist perceptions, destination image and tourist satisfaction on destination loyalty: a conceptual model. PASOS. Revista de Turismo y Patrimonio Cultural, 11 (3), 67-78.

[26] Suanmali, S. (2014). Factors affecting tourist satisfaction: An empirical study in the northern part of Thailand. In SHS web of Conferences (Vol. 12, p. 01027). EDP Sciences.

[27] Romli, A., Prickett, P., Setchi, R., \& Soe, S. (2015). Integrated eco-design decision-making for sustainable product development. International Journal of Production Research, $53(2), 549-571$.

[28] Middleton, V., \& Clarke, J. (2001). Marketing in travel and tourism. Jordan Hill.

[29] Kotler, P. \& Armstrong, G. (2010). Principle of Marketing. USA: Pearson. 